University of Pennsylvania Carey Law School

Penn Carey Law: Legal Scholarship Repository

Faculty Scholarship at Penn Carey Law

2017

\title{
Patent Pools and Related Technology Sharing
}

\author{
Erik Hovenkamp \\ Northwestern University \\ Herbert J. Hovenkamp \\ University of Pennsylvania Carey Law School
}

Follow this and additional works at: https://scholarship.law.upenn.edu/faculty_scholarship

Part of the Antitrust and Trade Regulation Commons, Economic Theory Commons, Entrepreneurial and Small Business Operations Commons, Growth and Development Commons, Intellectual Property Law Commons, Law and Economics Commons, and the Law and Society Commons

\section{Repository Citation}

Hovenkamp, Erik and Hovenkamp, Herbert J., "Patent Pools and Related Technology Sharing" (2017). Faculty Scholarship at Penn Carey Law. 1766.

https://scholarship.law.upenn.edu/faculty_scholarship/1766

This Book Chapter is brought to you for free and open access by Penn Carey Law: Legal Scholarship Repository. It has been accepted for inclusion in Faculty Scholarship at Penn Carey Law by an authorized administrator of Penn Carey Law: Legal Scholarship Repository. For more information, please contact PennlawIR@law.upenn.edu. 


\title{
PATENT POOLS AND RELATED TECHNOLOGY SHARING
}

\author{
Erik Hovenkamp* \\ Herbert Hovenkamp***
}

\section{Introduction}

A patent "pool" is an arrangement under which patent holders in a common technology or market commit their patents to a single holder, who then licenses them out to the original patentees and perhaps to outsiders. Structures vary, however, and may involve simple cross licensing rather than a separate holder (Hovenkamp, et al., 2015; Mattioli 2014; Lerner, Strojwas $\&$ Tirole, 2007). Licensors in a pool can include both practicing and non-practicing entities. Licensees are of course practicing entities. The copyright blanket license, which has provoked some antitrust litigation, ${ }^{1}$ is not really a pool because the artist members do little licensing to one another. Rather, artists and other copyright holders grant a nonexclusive license to a central clearinghouse, which then gives a blanket license to the entire portfolio to outside licensees such as radio stations. In addition are several open source licensing arrangements, which largely involve agreements to share royalty-free access to copyrighted works. ${ }^{2}$

The payoffs to pooling include both revenue earned as a licensor, and technology acquired by the pool member as licensee. Public effects can also be significant. For example, technology sharing of complementary patents can improve product quality and variety. In some information technology markets pools can prevent patents from becoming a costly obstacle to innovation by clearing channels of technology transfer. For "essential" patents, or patents incorporated into networks by a standard setting organization (SSO), a pool might enable competitive production by giving multiple firms access to the needed technology. (Lerner \& Tirole, 2004). Pools can also be used to fix product prices or reduce output, however. Further, they can facilitate concerted refusals to deal, or boycotts directed against competing technologies outside the pool. ${ }^{3}$ In sum, the private and social benefits to pooling can be substantial, but some threats to competition cannot be ignored.

To illustrate, suppose that one toaster maker has invented a device that detects accurately when bread is toasted just enough. Another maker has invented a device that senses how wide the bread is and moves the heating elements just the right distance away. These devices are complements in most scenarios. A toaster might have neither of them, either one, or both. Further, if customers value both, having both would make a toaster more valuable.

\footnotetext{
* Northwestern Univ. Department of Economics

** Ben V. \& Dorothy Willie Professor of Law, University of Iowa

${ }^{1}$ E.g., Broadcast Music v. Columbia Broadcasting Sys., 441 U.S. 1 (1979).

${ }^{2}$ One prominent example is the Android operating system. See

https://source.android.com/source/licenses.html.

${ }^{3}$ E.g., United States v. Singer Mfg. Co., 374 U.S. 174 (1963).
} 
The two toaster makers might do one or more of the following: 1) they might pool or "cross license," enabling both manufacturers to make toasters including both features. 2) They might additionally agree to issue licenses to other toaster makers, thus enabling third parties to make toasters with both features as well; in so doing, they might jointly agree on the price of a joint license; or they might agree to specify the price at which toasters produced under this joint license agreement are sold, or the number that can be made under the license. 3) They might make no agreement at all about licensing others, thus leaving each firm to decide whether to license out its particular feature. Or 4) they might agree with each other that neither will license its feature to third parties. While technology sharing between the two manufacturers is efficient, creating a more desirable product or lowering production costs, the various limitations on price or quantity or the limitations on third party production might all pose competitive threats. Further, there might be less restrictive alternatives that can achieve similar goals but without the competitive injury. Most antitrust challenges to patent pools require analysis under the rule of reason, which requires proof of market power, or the absence of competitive alternatives, and anticompetitive effects (Areeda \& Hovenkamp, 2010, Ch. 15).

Historically, most pools involved situations where each patent was presumed to make a significant contribution to the final product. More recently, particularly in information technologies, individual patents have grown much smaller in relation to product value. Some products such as digital video or cell phones now arguably embody thousands of patents. In addition, much of the current debate over poor patent quality is focused on these areas.

\section{Traditional Considerations-- Complements vs. Substitutes}

A traditional justification for patent pools is that they facilitate improved products by uniting complements, which are two things that are more valuable when used together. ${ }^{4}$ Sharing of complementary patents means that licensees can then employ all the patents in their product, rather than creating silos in which each manufacturer incorporates only its own patented features. In the toaster example, customers can buy toasters with both patented features. By contrast, if the patents are substitutes -- i.e., if each one performs a version of the same thing -- then manufacturers will ordinarily use one of the alternatives but not more. In that case crosslicensing of the patents is more suspicious and may facilitate price fixing. (Gilbert, 2004; Santore, 2010).

The substitutes/complements distinction is helpful for understanding the basic benefits and costs of cross-licensing. For example, it has been shown that patent pools increase welfare when included patents are perfect complements (i.e., they have no value unless they are used together), and decrease welfare when they are perfect substitutes (i.e., one is as good as the other but no one needs both) (Shapiro, 2001).

\footnotetext{
${ }^{4}$ See, e.g., Standard Oil Co. v. United States, 283 U.S. 163 (1931).
} 


\section{Avoiding Royalty Stacking and Holdup}

"Stacking" occurs when multiple sellers of complementary or vertically related products each have some market power but are unable to coordinate their output. The result is double marginalization. (Heller \& Eisenberg, 1998; Lemley \& Shapiro, 2007; Hovenkamp \& Hovenkamp, 2015) For example, if two patentees who each have market power should license individually, the sum of the two license fees will be greater than if they joined together and coordinated their price. Under traditional assumptions, double marginalization not only results in lower output and higher prices for consumers, it also injures sellers who are unable to coordinate their output. That is, the resulting price is higher than the monopoly profitmaximizing price. Pooling addresses this problem by permitting licensor participants to coordinate their prices and output.

The holdup problem is related, and occurs when licensing of essential technology occurs sequentially. For example, once a manufacturer has settled on technology A, its range of subsequent technology decisions narrows, and this may give the owners of a secondary technology power to charge more. The problem resembles that of the highway builder planning a route. Before any construction begins the land market is competitive. As soon as the builder makes a commitment to a certain route and starts building, however, the range of remaining options narrows. As a result the price can be expected to rise. A more competitive solution would be for the builder to "package" parcels of land along alternative routes in advance and then let the landowners bid against each other to sell the entire package. Patent pooling accomplishes the same thing by permitting packages of complementary technologies that make up a product to be sold simultaneously.

\section{"Blocking" patents}

Two patents are said to be "blocking" when practice of one requires infringement (or a license) of the other. Blocking applies to individual patent claims, rather than the patent as a whole. Unlicensed practice of only one claim constitutes infringement. In a two-way block neither patent can be practiced without a license to the other. In the more common one-way block, patent A cannot be practiced without a license to B, but B can be practiced without a license to A. ${ }^{5}$ So-called "improvement" patents are frequently one-way blocking patents. (Lemley, 1997) That is, if B is an improvement patent on A, then the only way to make use of the B improvement would be to have a license to A as well. However, the owner of original A can still practice it without a license to $\mathrm{B}$. The courts all agree that mandatory package licensing of blocking patents cannot be unlawful. ${ }^{6}$ It follows that two separate owners of blocking patents

\footnotetext{
${ }^{5}$ For a decision relying on the distinction, see Carpet Seaming Tape Licensing corp. v. Best Seam, Inc., 616 F.2d 1133, 1138 (9th Cir. 1980).

${ }^{6}$ E.g., Standard Oil Co. v. United States, 283 U.S. 163 (1931); International Mfg. Co. v. Landon, Inc., 336 F.2d 723 (9th Cir. 1964); Int'1 Mfg.Co. v. Landon, Inc., 336 F.2d 723, 729 (9th Cir. 1964) (“No
} 
should be able to pool them and insist on licensing them together. The Line Material case involved such a situation. The Supreme Court condemned the pool, but not because the members pooled. Rather, they additionally agreed to stipulate the price at which the licensed product could be sold. ${ }^{7}$

"Blocking" patents are necessarily complements with respect to blocking claims, but in other ways they may function as substitutes. A good, litigated example is the Philips decision, which involved a pool of technologies for rewritable compact discs. ${ }^{8}$ (Bohannan \& Hovenkamp, 2011; Bohannan \& Hovenkamp, 2012) One of the patents at issue employed an analog method for locating the stylus on the disc, while another patent employed a digital method. A manufacturer would use one of these technologies or the other, but not both. However, the analog method wrote on at least one claim in the digital patent, meaning that one could not practice the analog patent without licensing the digital patent. That is, the patents functioned as both substitutes and as one-way complements with respect to the blocking claim.

As the Philips case suggests, blocking patents can create a special case of patent complementarity. Two patented inventions may appear to be substitutes for most purposes, but a single conflicting claim can turn the patents into complements, at least for devices that practice that particular claim. Courts have observed that a large information technologies pool might contain hundreds of potentially blocking relationships that are unlikely to be identified without costly and time-consuming litigation. ${ }^{9}$

\section{Tying and "Unwanted" Tied Products}

The patents in a pool are typically offered to outside licensees as a bundle. They are either not licensed separately or else separate licensing costs more per patent. The antitrust tying problem arises when a licensee claims that it can obtain the desired patents (the "tying" product) only by taking the remainder of the bundle (the "tied" product). Tying complaints are most likely when licenses from patentees into the pool are exclusive, meaning that outsiders cannot obtain a license except through the pool. If the licenses are nonexclusive then licensees might be able to avoid the pool altogether.

The antitrust law of tying requires a tie of "separate products," market power in the tying product, and some kind of harmful effect on competition (Hovenkamp, 2015b). An unlawful

commercially feasible device could be manufactured under one of the patents without infringing the other").

${ }^{7}$ United States v. Line Material, 333 U.S. 287 (1948).

${ }^{8}$ U.S. Philips corp. v. ITC, 424 F.3d 1179, 1193 (Fed. Cir. 2005).

${ }^{9}$ Nero AG v. MPEG LA, L.L.C., 2010 WL 4366448 (C.D. Cal. Sep. 14, 2010). 
antitrust tie can also be found when a seller gives a lower price to someone who takes two products together than for those who make separate purchases. ${ }^{10}$

The general rule for establishing competitive harm from tying is that the tie must foreclose, or exclude, competition, typically in the tied product market. Most antitrust challenges to patent pool ties allege that the licensee really wants a smaller set of patents than the pool offers. He does not want the tied patents at all, from any seller. ${ }^{11}$ But the purpose of the antitrust laws is to promote competition, not merely to regulate the size of packages, and thus these challenges typically fail. For example, it is not unlawful for a land owner to insist on selling her 100 acre farm as a single parcel rather than cutting out a single acre at a particular buyer's insistence.

The unwanted tied product rationale, however, also suggests that the patents in the pool are not all complements, at least not for this particular purchaser. If the patents were substitutes the licensee would want only one of them, and the others would clearly be "unwanted." If the patents were complements for that particular licensee, however, the licensee would want both.

An important qualifier is that although the licensee may want both of them he may not want both from the same seller. A bundle can sometimes violate the antitrust laws if the licensee wants complementary technology, but from a different seller. Suppose that a pool includes patents $\mathrm{A}$ and $\mathrm{B}$, which are complements. However, an outside patentee has also created patented technology B', which performs the same function as B. In this case the pool can exclude B' by forcing the purchaser to take A and B together. To be sure, he might be able to license B' separately, but his incentive is lessened to the extent that the pool license already covers B. It effectively forces the licensor of B' to compete with a price of zero. ${ }^{12}$ In this case even the pooling of complementary patents can cause competitive harm.

\section{Limitations on the Complement/Substitute Distinction}

The substitute/complement distinction has a robust history and is a helpful way of thinking about competitive problems in traditional patent pools. In many of the pools commonly seen today, however, the distinction is less important. Intermediate cases between perfect complements and perfect substitutes are far more numerous and also more complex. For example, patents may block one another in some uses but not others and even patents that are predominantly substitutes can have blocking claims, requiring that they be used together. (Bohannan \& Hovenkamp, 2012).

\footnotetext{
${ }^{10}$ Collins Inkjet Corp. v. Eastman Kodak Co., 781 F.3d 264 (6th Cir. 2015), cert. petition filed (granting preliminary injunction).

${ }^{11}$ E.g., Nero AG v. MPEG LA, L.L.C., 2010 WL 4366448 (C.D. Cal. Sep. 14, 2010).

${ }^{12}$ Grid Sys. Corp. v. Texas Instruments, Inc., 771 F. Supp. 1033 (N.D. Cal. 1991) (sustaining antitrust complaint on this theory).
} 
The subject/complement relationship may depend not merely on the patents but also on the nature of the licensees' products. For example, the MPEG-LA pool licenses thousands of digital video patents to a wide variety of manufacturers of cell phones (both traditional and smart phones), cameras, televisions, computer displays, digital storage devices, video and other image editing and processing software, and so on. Some of these products both generate and display video content. Some do only one and a few do neither. Not all licensees from MPEG-LA use every patent or perhaps even more than a small number. Some may incorporate both of two particular patents; others may incorporate one but not the other. As a result, for one manufacturer two patents may operate as complements while for another they are either substitutes or unrelated.

Further, the products themselves may function as either complements or substitutes. For example, an operating system and a web browser are complementary in the sense that each performs some computer functions that the other cannot, and consumers often want both. On the other hand, consumers are increasingly able to perform tasks and run applications over the web, and this common ground makes them substitutable in some important respects. For example, a smartphone both takes and displays video, making it both a complement and a substitute for a large digital display.

\section{Reducing Costs of Boundary Delineation and Defense}

A more robust explanation for pooling in many markets comes out of the economics of transaction costs, which emphasizes the role of limited information and the costs of obtaining it, as well as uncertainty in bargaining and sharing. (Williamson, 1975; Hovenkamp, 2010; see also Orr, 2013) Pooling is an efficient solution to problems of technology development and transfer when determining patents' validity or identifying their boundaries is costly.

While manufacturers typically know their own products well, they are often uncertain about how many patents their products write on and, if so, how many of those patents are valid. For example, very extensive litigation in the market for cellular phones and related hand held electronic devices reveals a great deal of ambiguity about scope, narrow claim constructions, and high invalidity rates. By one estimate $90 \%$ of the claims in this market fail. (Muller, 2014). By another estimate the number of patents relevant to smartphone technology exceeds $250,000 .{ }^{13}$

In such cases the cost of identifying and defending boundaries can be higher than the cost of simply sharing access. Traditional resource pools often involve similar problems. These include fisheries, irrigation, grazing rights, and other low technology alternatives that have been subject to private, shared production for centuries (Ostrom, 1990). What these markets share in

\footnotetext{
${ }^{13}$ See https://www.techdirt.com/blog/innovation/articles/20121017/10480520734/there-are-250000active-patents-that-impact-smartphones-representing-one-six-active-patents-today.shtml.
} 
common is that the cost of sharing plus enforcing access and contribution rules is less than the cost of creating, identifying and enforcing individual boundaries.

For example common fisheries are created when many fishermen have the right to fish in certain waters, but the stock needs to be replenished and overfishing prevented. A traditional private property regime would address these problems by giving each fisherman an exclusive patch of water protected by a defensible boundary. If the fisherman fails to restock, his own yield suffers, as it will if he overfishes. The advantage of private property rights is that they create proper incentives by internalizing both the costs and payoffs of exploiting a resource.

In this case, however, the costs of dividing the pool into many individual parcels would be catastrophically high. First the group would have to decide on boundaries, then they would have to build fences and maintain them against both human and ichthyan violators, perhaps with devastating consequences for the yield. A better approach is to give each rights-holding fisherman managed access to the entire pool, with defined catch limits and an obligation to contribute to maintenance. (Bohannan \& Hovenkamp, 2012, pp. 325-364) This is simply a special case of Ronald Coase's Nature of the Firm, which showed that a business firm maximizes profits by choosing as between more and less profitable ways of accomplishing something. (Coase, 1937) In this case the payoff to sharing is greater than the payoff to individual rights of exclusion. As Elinor Ostrom observed in her studies of common pool resources, the use of such commons is product (technology) specific. For example, in some regions farmers maintain individual parcels for their crops while using a commons for grazing. (Ostrom, 1990, pp. 61-65)

The patent pool gives members instant and indemnified access to all patents in the pool. The pool owners need not worry about which patents the licensee may be practicing, and the licensee need not worry about whether or not it is infringing any particular patent in the pool, because its pool license grants it access to all. Of course the solution is incomplete to the extent that a user might infringe one or more patents that have not been licensed to the pool.

Gilbert (2004) recommends that antitrust authorities concentrate their enforcement activities against pools on weak patents. For many traditional pools that is sound advice. In information technologies pools with thousands of patents, however, it is probably not worth the enforcer's time to investigate every patent in a pool, except perhaps for identifying those that are clearly invalid on their face. Indeed, one might simply assume that several of these patents are quite weak and that many have indeterminate boundaries. The problem is that ex ante we don't know which ones, and the costs of claim construction and invalidity assessments can run to thousands of dollars per patent. One party in such litigation involving three patents spent $\$ 600,000$ just through claim construction. ${ }^{14}$

\section{Limited Importance of Delineating a Pool's Inner Boundaries}

\footnotetext{
${ }^{14}$ Eon-Net LP v. Flagstar Bancorp., 653 F.3d 1314 (Fed. Cir. 2011).
} 
An individual patent's boundaries distinguish its protected embodiments from noninfringing technology. But when multiple patents are aggregated what matters are the outer boundaries that separate the portfolio as a whole from outside patents or the public domain. So long as the relevant rights are somewhere in the portfolio, the parties do not need to delineate the boundaries of individual patents in order to strike a deal.

For example, if a landowner wants to sell his neighbor a license to walk through his meadow, the contract need not specify the exact boundaries of the path; it is much simpler to include the entire meadow, even though this is more than the neighbor requires. This likely benefits the neighbor, as he need not worry about mistakenly traveling slightly outside a narrowly-defined path, and it probably makes little difference to the landowner. Of course, if the parties were negotiating the sale of an exclusive strip of land for development, then they would want to specify precise boundaries.

Similarly, when a pool of patents is licensed, it is not necessary to trace out the exact set of pooled patents on which a licensee's product will read. For example, suppose a patent pool includes related patents $\mathrm{X}$ and $\mathrm{Y}$, whose boundaries are difficult to distinguish (perhaps because they arguably overlap). A licensee wants to secure the rights to produce something that definitely reads on patent $\mathrm{X}$, and may or may not also read on patent $\mathrm{Y}$. But the value of the licensing application does not hinge on this question The parties might as well agree on a license for both $\mathrm{X}$ and $\mathrm{Y}$, because there is no reason why the terms of trade would be any different if they hired a lawyer to discern the inner boundary between $\mathrm{X}$ and $\mathrm{Y}$.

Of course, the portfolio would be worth less if a large number of its patents or its most desired ones were invalid or easily invented around. But these possibilities could just be priced into the license fee, and this would allow the parties to forgo the costs of boundary identification without affecting the expected terms of trade. Even if delineating a pool's inner boundaries were not prohibitively costly, it is not clear that the parties would derive a significant benefit from doing so. The value of the license to a product producer relates to the market value of its product in relation to costs: the product is not more valuable as it embodies more patents. The case law has often neglected this insight. Value is determined by the technology's contribution to the value of the licensee's product or process as well as the cost of substitutes, regardless of how individual IP rights are divided up.

Nevertheless, a pool's inner boundaries are still important in determining how the pool's proceeds will be allocated among contributing members; a party who contributes more patents or whose patents are practiced more often may expect to get paid more. But this problem need not affect the fees charged by the pool. Indeed, a pool's objective is typically to choose the license fees that maximize aggregate licensing revenues, regardless of how those revenues are subsequently divided among members. This is best for each member, no matter its percentagestake in the pool's revenues. 


\section{Pricing in Patent Pools vs. Conventional Bundling}

A conventional bundle involves the sale of two or more physical components, such as a camera and film, both of which are rivalrous goods. By contrast, in a nonexclusive license to a patent pool the licensor retains the undiminished right to use or license the right. Indeed, even transaction costs need not be any higher when a patentee licenses a group of patents than when it licenses only one. These things are invariably true if the licensee does not practice these patents. Even if it does, however, practicing imposes costs on the licensor only if it adversely affects the licensor (as in the case of licensing a patent to a competitor) or if such use reduces other parties' willingness to pay for a license. In sum, if the licensee does not use all patents in the bundle, then the inclusion of the unused licenses has no impact on either party. Consequently, the price of the bundle will reflect the fact that many of the included licenses neither benefit the licensee nor impose costs on the licensor, and this suggests that a representative licensee is not necessarily being forced to pay extra for something it does not want.

The bundle of licenses in a patent pool resembles a restaurant buffet. Buffets are common even though ownership is clear, as are the "boundaries" between individual items. The entry fee gives the customer a nonexclusive right to select food options in any combination he wants, but the buffet serves other diners simultaneously. Each consumer takes a subset of the available options, and the price will reflect the average cost of such subsets - not the cost of providing every food option to every consumer. Of course, if the buffet adds a new food option, this will affect some consumers' choices; some will take the new option and a little less of something else, but this will not necessarily make consumers' choices more costly on average. A representative consumer is not being made to pay extra for anything he does not want, so a customer who chooses only beef does not have a "tying" claim against the restaurant for forcing it to pay for numerous unwanted products. Indeed, to the extent beef is more costly than other options, such a customer may actually impose higher costs on the restaurant. The more accurate characterization of buffets is that, on average, consumers pay only for what they like but also receive options for everything else. In the context of patent pooling, this suggests that prices do not reflect the value of all pooled patents, but rather the value of a representative application, most of which rely on only a subset of the patents.

\section{Pooling and Collusion Threats}

While most patent pools are socially beneficial overall, certain practices or structures can pose competitive problems. The biggest antitrust risk from pooling is collusion, and the threat of collusion depends on two things. First is the market structure and the power of the pool within its market. Second is the nature of pricing and exclusivity arrangements within the pool. (Merges, 1996) 
On the first issue, cartels profit only if they have market power. Patent pools often cover an entire industry, but they can also be limited to a small number of firms in a larger market that have decided to share a unique technology. Whether that technology confers sufficient advantage to enable them to raise their prices above cost is an empirical question. Naked price fixing is generally said to be unlawful per se. The courts have been hesitant to apply the per se rule to agreements within a pool, however. Softer forms of price-affecting conduct, as well as conduct that is directly implicated in joint production, is generally treated under antitrust's rule of reason. This means that the pool's market power must be estimated.

The antitrust issue is also complicated by the presence of the Patent Act, whose specific provisions generally control the much more general provisions of the antitrust laws. For example, the Patent Act authorizes patentees to grant licenses, including exclusive licenses. ${ }^{15}$ It also states that a patentee's unilateral refusal to license cannot be unlawful, although it does not say the same thing about concerted refusals. ${ }^{16}$ One can presume that the mere authorization to engage in a practice does not imply an authorization to do so anticompetitively -- at least, that is how the Supreme Court has interpreted statutory authorizations in other contexts. ${ }^{17}$ For example, while Section 271 authorizes a "patent owner" to refuse to license its patent, it says nothing about agreements among numerous patent owners to refuse to license outside the pool, nor does it extend that right to nonexclusive licensees.

Specific sharing agreements among pool members come in numerous varieties. They may simply agree to share technology without any royalty. Alternatively, one or any subset of pool members may charge other members a royalty -- something that is likely to occur if the participants have patent portfolios with different values, or if some members have no patents and thus participate only as licensees. The royalty rate might be flat, annualized, or most commonly, an amount based on the number of units that a licensee produces or its revenue. In addition, members may agree to limit the number of units embodying pooled patents that any member may produce.

\section{Express Collusion}

Since market exchange cannot generally take place without an agreement on price, there is nothing inherently suspicious about a pool's agreements concerning how royalties on pooled patents are computed. Nothing is inherently suspicious about agreements in which members who have contributed smaller portfolios pay more than those with larger portfolios, or licensees with no portfolios at all pay more than contributing licensors. These are all essential

\footnotetext{
1535 U.S.C. § 261.

${ }^{16} 35$ U.S.C. $\$ 271(\mathrm{~d})(4)$.

${ }^{17}$ E.g., FTC v. Phoebe-Putney, 133 S. Ct. 1003 (2013) (state statute authorizing one hospital to acquire another did not authorize merger that violated antitrust laws).
} 
characteristics of bargaining behavior. Further, Section 261 of the Patent Act places no limits on how royalties are computed.

What the Patent Act does not justify, however, is price fixing of the products that pool members sell. Nevertheless, the Supreme Court case law in this area is troublesome. In its 1902 Bement decision the court permitted pool members to fix the price of agricultural harrows produced with shared technology. ${ }^{18}$ The Court adhered to a version of that rule in the much criticized General Electric decision, upholding an agreement in which patentee GE licensed Westinghouse to produce incandescent bulbs under its patents but specified Westinghouse's selling price. ${ }^{19}$ By contrast, in Line Materials the Court condemned product price fixing contained in a cross-licensing agreement involving complementary patents. More recently, dicta in the Supreme Court's majority opinion in Actavis expressly embraced Line Materials and expressly limited $G E$ to a license price fix between a single licensee and single licensor. ${ }^{20}$

Express output limitations function much like price fixing agreements. Indeed, cartels often operate more successfully by limiting output and letting the price rise to the new market level, rather than by fixing the price directly. (Stigler, 1962) Nevertheless, inherent in the concept of a license is specification of a certain amount, such as the right to make 1000 units per year. In any event, it is important to remember that output limitations refer to the number of times a patent can be practiced, not to the number of times a good can be sold. For example, if a patentee licenses a manufacturer to make 1000 toasters weekly with the patentee's toast-detection sensor, the manufacturer is still free to make as many toasters as it pleases that do not practice that patent. An attempt to limit those would be a per se unlawful output restriction.

The policy concerns respecting pool output agreements differ from those that govern more traditional common pool resources. The traditional resource placed in a common pool is rivalrous, or subtractive, meaning that each person's use diminishes what is left for others. For example, catch limits on a fishery commons are not inherently suspicious even though it resembles a cartel. The catch limit is necessary in order to prevent overfishing. Patents are nonrivalrous, however. $^{21}$ (See Bohannan \& Hovenkamp, 2012, 328-329) Absent a license restriction, if one of the two toaster makers in our previous illustration should increase its output by $50 \%$ that will not reduce the number of units that the competing manufacturer can make. Of course, it may produce a "congestion externality" to the extent that the remaining market for toasters is smaller. But that is nothing more than competition at work, and in fact social welfare is higher when patented inventions are more widely used. As a result, output limitations in

\footnotetext{
${ }^{18}$ Bement v. Nat'l Harrow Co., 186 U.S. 70 (1902).

${ }^{19}$ United States v. Gen. Elec. Co., 272 U.S. 476 (1926). For severe criticism of the rule, see Judge Posner's opinion in Asahi Glass co. v. Pentech Pharm., Inc., 289 F.Suppp.2d 986 (N.D. Ill. 2003).

${ }^{20}$ FTC v. Actavis, Inc., 133 S. Ct. 2223, 2225, 2231-2232 (2013), discussing United States v. Line Material Co., 333 U.S. 287 (1948).

${ }^{21}$ Justice Story made this error in Brooks v. Byam, 2 Story 525, 4 F. Cas. 261 (C.C. Mass. 1843).
} 
patent pools should be regarded with greater suspicion than output limitations for traditional common pool resources.

\section{Pool Exclusivity}

Patent pool "exclusivity" can take several forms. First, it can refer to the contract that each licensor has with the pool, asking whether that licensor is free to license to others outside of the pool. Second it can refer to the pool's willingness as licensee to accept an offered technology from an outsider for inclusion in the pool. Third it can refer to the pool's willingness as licensor to license to outsider manufacturers. Fourth, it can refer to field-of-use or other restrictions given to licensees from the pool. Nearly all of these arrangements are multilateral and thus are controlled by Section 1 of the Sherman Act. That does not mean, however, that they are unlawful.

No cartel can succeed unless it can reduce market-wide output. For this reason cartels are fastidious about policing the output of cartel members. For their part, the members have a strong incentive to cheat. At the cartel price, revenues are considerable higher than marginal cost, making cheating very profitable (Hovenkamp, 2015b $\S 4.1 \mathrm{a}$ ). This is particularly true in IP markets, where marginal costs are low to begin with. Each cheating sale produces considerable additional profit.

For these reasons, nonexclusivity in pool licensing arrangements suggests that the pool is procompetitive, (Hovenkamp, 2015b, § 5.5c; Dep’t of Justice \& FTC, 2007; Greene, 2010) provided that nonexclusivity really means what it says. That is, there might be small pools with public nonexclusivity but tacit exclusivity requirements. Aside from that, however, a clear and public nonexclusivity requirement, particularly when the pool has a large number of members, significantly reduces the collusion risk.

Exclusive agreements between individual licensors and the pool are more difficult to analyze. First, the pool may be willing to pay more for exclusive licenses to the extent that they commit technology suppliers to that particular pool's technology, giving the pool an advantage over alternative licensing outlets. This may also enable the pool to develop its own distinct brand, with technology that cannot be readily copied by outsiders. ${ }^{22}$ In this sense they operate a little more like exclusive dealing or output contracts, which are competitive most of the time but can raise competition concerns when market power and foreclosure rates are sufficiently high (Hovenkamp, 2011, I1821).

The second type of exclusivity concerns the outside developer of technology who wants to include its patents in the pool but is denied. One clearly procompetitive explanation for the pool's refusal to accept an offeror's technology is that the excluded technology is inferior to or no better than technology that the pool already has. There are good reasons for a pool not to accept

\footnotetext{
${ }^{22}$ E.g., United States v. Sealy, Inc., 388 U.S. 350 (1967).
} 
an inferior substitute technology; namely, it will not make the pool products better and it might raise fears of collusion. If the prospective licensor's technology is simply unwanted by pool members, that also indicates lack of competitive harm. The firms in the pool have a right to make their own technology choices, even when they do so by agreement. Indeed, even a dominant network should not have an obligation to accept a set of licenses to a technology that its members do not want, and no concern about competition arises.

Competitive harm can occur when some pool members already have technology in the pool that competes with the excluded firm's superior technology. In that case the pool can operate as an anticompetitive boycott. ${ }^{23}$ Assessing the merits of such claims is difficult, because it may require the fact finder to assess the merits of the excluded technology. As a result it is essential to make sure that structural prerequisites are present. For example, an essential element in such a claim would be the existence of an influential pool member or members who own competing technology and have sufficient power to foist an inferior technology on others, perhaps by manipulating the process. ${ }^{24}$

The third type of exclusivity is the pool that licenses to others only selectively, perhaps only to member-licensors or perhaps to some others. Once again rule of reason treatment is generally appropriate. No general antitrust rule requires a joint venture to share its technology with rivals, particularly in small or specialized ventures whose formation required significant investment. The main reason is to limit free riding on the members' costly efforts. For example, three firms may agree with each other to cross-license their patents and develop a new product. A fourth stands aside, wishing not to assume the risk of failure. Then, after the venture succeeds, the fourth firms wants to join. An antitrust rule that permitted late joiners would operate as a disincentive to invest in the first place.

Larger, mostly-open pools present a different issue. If the pool controls a network, access to the pool may be essential for operation on the network. Selective exclusion may be a way of disciplining price cutting by refusing pool access. As a result, a practice that selectively denies pool access to price cutters or other aggressive firms could be unlawful. (Hovenkamp, 2012, II[2220-2224). Relatedly, as with exclusivity agreements limiting licensor-membership, a concerted refusal to license to a firm may be unlawful if it amounts to a group boycott that serves to restrain competition in a downstream product market.

The fourth type of exclusivity really concerns market divisions in the pool, and several of these have been prosecuted under the antitrust laws. These are most likely to be a threat when individual pool members dominate different market segments. The pool management might then

\footnotetext{
${ }^{23}$ E.g., Golden Bridge Tech., Inc. v. Motorola, Inc., 547 F.3d 266, 270-71 (5th Cir. 2008) (rejecting such a claim); see also TruePosition, Inc. v. LM Ericsson Tel. Co., No. 11-4574, 2012 WL 3584626, at *25 (E.D. Pa. Aug. 21, 2012) (sustaining a complaint); Cryptography Research Inc. v. Visa Int'l Serv. Ass'n, No. C 04-04143 JW, 2008 WL 5560873, at*6-7 (N.D. Cal. Aug. 13, 2008) (similar).

${ }^{24}$ Cf. Allied Tube \& Conduit Corp. v. Indian Head, Inc., 486 U.S. 492 (1988).
} 
use field-of-use restrictions on member-licensees to divide the market, thus preventing each member from entering competition with a different member. For example, Hartford-Empire condemned such an arrangement among firms whose pool divided the market for different types of glass bottles. ${ }^{25}$

Sometimes these various types of exclusivity can operate together and heighten antitrust concerns. For example, the pool's refusal to license a newcomer is potentially more harmful if the original licensor members of the pool also have exclusive license agreements. If these agreements are nonexclusive, then the manufacturer who is denied a pool license can still try to obtain essential patents from individual licensor members. ${ }^{26}$

\section{A Brief Note on FRAND}

Standard setting organizations often identify standards essential patents (SEPs) that cover an adopted and shared technology. In order to acquire SEP status participating patent owners must generally promise to license their patents to willing participants on fair, reasonable and non-discriminatory (FRAND) terms (Hovenkamp, 2015a; Lemley, 2002, Swanson \& Baumol, 2005). As a result, these pools are generally nonexclusive in the sense that anyone can become a licensee simply by agreeing to pay the FRAND royalty. The principal litigation has involved royalty computation ${ }^{27}$ and entitlement to an injunction. ${ }^{28}$

\section{Concluding Note: Pooling and Innovation Rates}

A large but quite inconclusive literature discusses the relationship between pooling and innovation. Conclusions are extremely sensitive to assumptions about patent strength and quality, about the relationship among the patents in a pool and the strength of alternatives outside the pool, about the impact on innovation of insiders vs. outsiders to the pool, and finally, about the strategic responses of participants. In addition are difficulties in assessing innovation rates. Counting patents issued per time period is relatively easy, but is not a good measure of innovation if patents are of low quality or if firms respond to the pool by altering their patenting behavior rather than their innovation behavior.

The existence of a pool may distort innovation behavior. For example, a firm might decide to protect a particular innovation with a trade secret rather than a patent in order to avoid committing it to a pool. Alternatively, it may rely on simple first mover advantages in order to avoid patent disclosure requirements. Another distortion results from how royalties are divided

\footnotetext{
${ }^{25}$ Hartford-Empire Co. v. United States, 323 U.S. 386, 392-400 (1945).

${ }^{26}$ E.g., United States v. Associated Patents, 134 F. Supp. 74 (E.D. Mich. 1955) (condemning agreement among manufacturers giving each exclusive rights to build particular types of machines and noting that pool members refused to license their patents outside the pool).

${ }^{27}$ E.g., Ericcson, Inc. v. D-Link Sys., Inc., 773 F.3d 1201 (Fed. Cir. 2014); Microsoft Corp. v. Motorola, Inc., 2013 WL 2111217 W.D. Wash. Apr. 25, 2013).

${ }^{28}$ Apple, Inc. v Motorola, Inc., 757 F.3d 1286 (Fed. Cir. 2014).
} 
up. For example, if the pool divides royalties by the number of patents, then pool members have an incentive to make patents thinner in order to increase their number. (Baron and Delcamp, 2015) Finally, one must distinguish anticipatory innovation which occurs when a patent pool is announced (Lerner \& Tirole, 2004; Dequiedt \& Versaevel, 2013), from equilibrium innovation which occurs on an ongoing basis after the pool is in operation (Baron \& Pohlmann, 2015).

A well-functioning patent pool should reduce the costs of sharing technology, which it can do by making it easier for manufacturers to assemble complements, eliminate double marginalization, or reduce the costs of defining or defending patent boundaries. Since all of these costs operate as a deadweight loss on innovation one would think that the impact of a well designed pool is positive. On the other side, pooling may reduce the appropriation value of innovations, particularly if pool members must commit in advance to dedicate new patents to the pool. In that case, rather than obtaining the entire return the pool member must contemplate sharing with others, and this may create common pool management problems. Each firm will have a tendency to shirk, profiting instead from the inventions of others.

The theoretical and empirical literature points in both directions, with most literature finding that most patent pools increase innovation rates (e.g., Baron \& Pohlmann, 2015; see also Shapiro, 2001; Lerner and Tirole, 2004; Mossoff, 2011), although there is also literature concluding to the contrary (e.g., Lampe \& Moser, 2010, 2013, 2016). Others find that pools of stronger patents tend to increase innovation while pools dominated by weaker patents more likely to be invalidated in litigation do not (Choi \& Gerlach, 2013).

As a general proposition a pool should increase the demand for innovation of complements to the pool. First of all, access to the existing technology by pool members should be guaranteed and cheaper. To the extent the pool reduces licensing costs and eliminates royalty stacking the cost of further improvements should decline. When innovation is cumulative the development of new technology may require the licensing of existing technology with multiple patent holders. Pooling can reduce these costs and thus facilitate cumulative innovation. (Scotchmer, 1991).

\section{References}

Areeda, Phillip E. \& Herbert Hovenkamp (2010), Antitrust Law, Vol. 7, New York: Wolters Kluwer

Baron, Justus \& Henry Delcamp, The Strategies of Patent Introduction into Patent Pools (Northwestern Univ. Working Paper, 2015), available at https://www.law.northwestern.edu/researchfaculty/searlecenter/innovationeconomics/documents/The_strategies_of_patent_introduction_int o_pools_2013.pdf

Baron, Justus and Tim Pohlmann (2015), The Effect of Patent Pools on Patenting and Innovation -- Evidence from Contemporary Technology Standards (Northwestern Univ. Working paper, 
2015), available at http://www.law.northwestern.edu/researchfaculty/searlecenter/innovationeconomics/documents/Baron_Pohlmann_effect_of_patents.pdf

Bohannan, Christina \& Herbert Hovenkamp (2011), Concerted Refusals to License Intellectual Property Rights, 1 Harv. Bus. L. Rev. Bull. 21

Bohannan, Christina \& Herbert Hovenkamp (2012), Creation Without Restraint: Promoting Liberty and Rivalry in Innovation, New York: Oxford

Choi, Jay Pil and Heiko Gerlach, Patent Pools, Litigation and Innovation (Cesifo Working Paper, Oct. 24, 2013), available at http://papers.ssrn.com/sol3/papers.cfm?abstract_id=2344689

Coase, Ronald H. (1937), The Nature of the Firm, 4 Economics (n.s.).

Dequiedt, Vianney \& Bruno Versaevel (2013), Patent Pools and Dynamic R\&D Incentives, 36 Int'l Rev. L. \& Econ. 59

Gilbert, Richard J. (2004), Antitrust for Patent Pools: A Century of Policy Evolution, 2004 Stan. Tech. L. Rev. 3

Greene, Hillary (2010), Patent Pooling Behind the Veil of Uncertainty: Antitrust, Competition Policy, and the Vaccine Industry, 90 B.U. L. Rev. 1397

Heller, Michael A. \& Rebecca S. Eisenberg (1998), Can Patents Deter Innovation? The Anticommons in Biomedical Research, 280 Sci. 698

Hovenkamp, Erik N. \& Herbert Hovenkamp (2015), "Tying Arrangements," Oxford Handbook of International Antitrust Economics, New York and London: Oxford Univ. Press

Hovenkamp, Herbert (2010), Harvard, Chicago and Transaction Costs Economics in Antitrust Analysis, 55 Antitrust Bull. 613

Hovenkamp, Herbert (2011), Antitrust Law, Vol. 11, New York: Wolters Kluwer Hovenkamp, Herbert (2012), Antitrust Law, Vol. 13, New York: Wolters Kluwer Hovenkamp, Herbert (2015a), Antitrust and the Patent System: A Reexamination, 76 OSU L.J. 467.

Hovenkamp, Herbert (2015b), Federal Antitrust Policy: the Law of Competition and its Practice ( $5^{\mathrm{TH}}$ ed.), St. Paul, MN, West Academic

Hovenkamp, Herbert, et al. (2015), IP and Antitrust: An Analysis of Antitrust Principles Applied to Intellectual Property Law, New York: Wolters Kluwer 
Lampe, Ryan \& Petra Moser (2010), Do Patent Pools Encourage Innovation? Evidence from the 19th-Century Sewing Machine Industry, 70 J. Econ. Hist. 898-920

Lampe, Ryan \& Petra Moser (2013), Patent Pools and Innovation in Substitutes -- Evidence from the 19th Century Sewing Industry, 44 RAND J. Econ 757-778

Lampe, Ryan \& Petra Moser (2016), Patent Pools, Competition, and Innovation -- Evidence from 20 United States Industries under the New Deal, 32 J. L. Econ. \& Organ. (forthcoming)

Lemley, Mark A. (1997), The Economics of Improvement in Intellectual Property Law, 75 Tex. L. Rev. 993.

Lemley, Mark A. (2002), Intellectual Property Rights and Standard-Setting Organizations, 90 Calif. L. Rev. 1889.

Lemley, Mark A. and Carl Shapiro (2007), Patent Holdup and Royalty Stacking, 85 Tex. L. Rev. 2163.

Lerner, Josh, Marcin Strojwas, \& Jean Tirole (2007), The Design of Patent Pools: The Determinants of Licensing Rules, 38 Rand J. Econ. 610.

Lerner, Josh \& Jean Tirole (2004), Efficient Patent Pools, 94 Am. Econ. Rev. 691.

Mattioli, Michael (2014), Power and Governance in Patent Pools, 27 Harv. J.L. \& Tech. 421.

Merges, Robert P. (1996), Contracting into Liability Rules: Intellectual Property Rights and Collective Rights Organizations, 84 Cal. L. Rev. 1293.

Mossoff, Adam (2011), The Rise and Fall of the First American Patent Thicket: The Sewing Machine War of the 1850s, 53 Ariz. L. Rev. 1654.

Muller, Florian (2014), "Analysis of 222 Smartphone Patent Assertions," available at http://www.fosspatents.com/2014/10/analysis-of-222-smartphone-patent.html.

Orr, Justin R. (2013), patent Aggregation: Models, Harms, and the Limited Role of Antitrust, 28 Berkeley Tech. L. J. 525.

Ostrom, Elinor (1990), Governing the Commons: The Evolution of Institutions for Collective Action, New York: Cambridge Univ. Press

Santore, Rudy, et al. (2010), Patent Pools as a Solution to Efficient Licensing of Complementary Patents? Some Experimental Evidence, 53 J.L. \& Econ. 167.

Scotchmer, Suzanne (2006), Innovation and Incentives, Cambridge: MIT Press 
Shapiro, Carl (2001) "Navigating the Patent Thicket: Cross Licenses, Patent Pools, and Standard-Setting," in A. Jaffe, J. Lerner, and S. Stern eds., Innovation Policy and the Economy, vol. 1, Cambridge: MIT Press

Stigler, George J. (1962), A Theory of Oligopoly, 72 J. Pol. Econ. 44.

Swanson, Daniel G. \& William J. Baumol (2005), Reasonable and Nondiscriminatory (RAND) Royalties, Standards Selection, and Control of Market Power, 73 Antitrust L.J. 1

U.S. Dep't of Justice \& FTC (2007), Antitrust Enforcement and Intellectual Property Rights: Promotingnnovation and Competition.

Williamson, Oliver E. (1975), Markets and Hierarchies: Analysis and Antitrust Implications, New York: The Free Press 